\title{
HUBUNGAN ANTARA REGULASI EMOSI DENGAN STRES AKADEMIK PADA MAHASISWA FAKULTAS KEDOKTERAN UNIVERSITAS HALU OLEO
}

\author{
RELATIONSHIP BETWEEN EMOTION REGULATION WITH \\ ACADEMIC STRESS ON STUDENTS OF MEDICAL FACULTY \\ HALU OLEO UNIVERSITY
}

\author{
Abdul Rahman Kadi ${ }^{1}$, Hartati Bahar ${ }^{2} \&$ Ida Sriwaty Sunarjo $^{3}$ \\ Program Studi Psikologi \\ Fakultas Keguruan dan Ilmu Pendidikan, Universitas Halu Oleo \\ abdrahmankd@gmail.com ${ }^{1}, \underline{\text { hartati.bahar@uho.ac.id }}^{2}, \underline{\text { ida sunarjo@ymail.com }}^{3}$
}

\begin{abstract}
ABSTRAK: Stres Akademik merupakan suatu respon yang muncul karena terlalu banyaknya tuntutan dan tugas yang harus dikerjakan oleh mahasiswa, tuntutan ini dapat memberikan dampak negatif psikologis dan juga pencapaian akademik mereka, dampak negatif yang dihasilkan tidak selalu dialami oleh mahasiswa, perbedaan ini mungkin dapat disebabkan oleh regulasi emosi pada masing-masing mahasiswa, dimana regulasi emosi dapat mengontrol dan mengekspresikan emosi yang mereka alami oleh sebab itu penelitian ini bertujuan untuk melihat hubungan antara regulasi emosi dengan stres akademik pada mahasiswa Fakultas Kedokteran Universitas Halu Oleo. Subjek penelitian ini berjumlah 79 orang dari angkatan 2015-2018. Teknik pengambilan sampel menggunakan Stratified Random Sampling. Pengumpulan data menggunakan Difficulties in Emotional Regulation Scale (DERS) yang dimodifikasi oleh peneliti dan juga Student Academic Stres Scale (SASS). Metode analisis data menggunakan uji korelasi Product Moment Pearson. Hasil analisis data didapatkan nilai signifikansi korelasi $(\rho)$ sebesar 0,000 dan korelasi pearson sebesar $-0,723$. Sehingga dapat disimpulkan bahwa terdapat hubungan negatif signifikan antara regulasi emosi dan stres akademik pada mahasiswa Fakultas Kedokteran Universitas Halu Oleo.
\end{abstract}

Kata Kunci : Regulasi Emosi, Stres Akademik, Mahasiswa Fakultas Kedokteran

\begin{abstract}
Academic stress is a response that arises because there are too many demands and tasks to be done by students, these demands can have a negative psychological impact and also their academic achievement, the negative impact generated is not always experienced by students, this difference may be caused by emotional regulation in each student, where the regulation of emotions can control and express emotions they experience, therefore this research aims to determine the relationship between emotional regulation and academic stress in the students of Medical Faculty Halu Oleo University. The subjects of this study were 79 people from the 2015-2018 class. The sampling technique in this study uses Stratified Random Sampling. Data collection uses Difficulties in Emotional Regulation Scale (DERS) modified by researchers and Student Academic Stress Scale (SASS). The data of this research has been analysis with Pearson Product Moment correlation test. The results of data analysis obtained a significance value of correlation ( $\rho$ ) of 0,000 and Pearson correlation of 0.723. So it can be concluded that there is a significant negative relationship between emotional regulation and academic stress on students of Medical Faculty, University of Halu Oleo.
\end{abstract}

Keywords :Emotion Regulation, Academic Stress, Student of Medical Faculty 


\section{Pendahuluan}

Mahasiswa merupakan individu yang menuntut ilmu ataupun belajar pada salah satu jenis perguruan tinggi, yang terdiri dari Akademik, Politeknik, Sekolah Tinggi, Institut dan Universitas (Hartaji, 2012), yang dimana mereka dituntut untuk berprestasi semaksimal mungkin karena hal tersebut merupakan bagian dari ukuran keberhasilan mahasiswa (York, Gibson, \& Rakin, 2015).

Mahasiswa tentu saja tidak lepas dari tugas-tugas yang berhubungan dengan laporan, makalah, praktikum, ujian, kuis dan tugas-tugas kampus lainnya, dan hal ini merupakan bagian dari tuntutan akademik mahasiswa. Tuntutan ini dapat memberikan tekanan kepada mahasiswa karena adanya ketidakmampuan mahasiswa untuk memenuhi tuntutan tersebut, hal ini dapat disebabkan karena adanya perbedaan tuntutan belajar dari masa sekolah menengah dengan masa perkuliahan, yang meliputi perbedaan kinerja akademik, kesiapan sosial untuk saling berinteraksi dengan dosen maupun teman sebaya, sampai pada pendirian dalam pengerjaan tugas yang saling bertentangan dengan teman sebaya (Geng \& Midford, 2015). Selain itu alasan lain mengapa mahasiswa tidak mampu memenuhi tuntutan akademiknya yaitu adanya keterbatasan waktu dan ketidakmampuan mahasiswa dalam menguasai bidang ilmu pengetahuan yang mereka pelajari. Tekanan yang disebabkan karena ketidakmampuan mahasiswa dalam menyelesaikan tuntutan akademiknya dalam perkuliahan, dapat memicu terjadinya stres akademik.

Menurut Barseli dan Ifdil (2017), stres akademik muncul ketika adanya tekanan yang disebabkan oleh suatu kondisi akademik tertentu, tekanan ini melahirkan respon berupa reaksi fisik, perilaku, pikiran maupun emosi negatif yang muncul akibat tuntutan akademik yang mereka hadapi. Umumnya stres akademik pada mahasiswa merupakan hal yang normal terjadi dan hampir setiap mahasiswa pernah mengalami stres dalam menjalani studinya, bahkan stres dapat membantu mahasiswa lebih aktif dan produktif (Alsulami dkk, 2018), namun apabila stres yang dialami oleh mahasiswa terjadi terus-menerus dan berkepanjangan maka dapat memberikan dampak negatif dalam pencapaian akademik mahasiswa (Olape, Lasiele, Chiaka, \& Abidoye, 2017).

Stres akademik tentu saja pernah dialami oleh setiap mahasiswa tidak terkecuali mahasiswa kedokteran. Mahasiswa kedokteran merupakan salah satu mahasiswa yang rentan terkena stres akademik dalam menempuh studinya, bahkan stres yang dialaminya lebih tinggi dibandingkan dengan mahasiswa program studi lain di non sektor medis (Jafri dkk, 2017). Hal ini tidak lain disebabkan karena mahasiswa kedokteran dibebani oleh banyaknya tuntutan pelajaran dan mereka dituntut untuk mempelajari banyak informasi baru dalam waktu singkat sebelum mereka mengikuti ujian dan evaluasi, karena itu, mereka tidak punya banyak waktu untuk meninjau kembali apa yang telah mereka pelajari sehingga menyebabkan perasaan kecewa kerena ketidakmampuan untuk menangani informasi secara sekaligus (Yusoff $\mathrm{dkk}$, 2013).

Banyak hasil riset yang menjelaskan bahwa mahasiswa kedokteran mengalami stres akademik dalam menempuh studinya, dimana dikutip dari BeyondBlue yang merupakan organisasi kesehatan mental di Australia, pada tahun 2013 telah melakukan wawancara kepada 14.000 dokter dan mahasiswa kedokteran. Hasil survey menyatakan bahwa $43 \%$ dari mahasiswa kedokteran memiliki kemungkinan tinggi untuk mengalami gangguan kejiwaan minor dan 9,2\% memiliki tingkat tekanan psikologis yang sangat tinggi, selain itu 19,2\%, mahasiswa kedokteran memiliki pikiran untuk melakukan bunuh diri dan 52,3\% mengalami kelelahan emosional (https://www.beyondblue.org.au/media/me 
dia-releases/media-releases/action-toimprove-the-mental-health-of-australiandoctors-and-medical-students).

Penelitian serupa juga dilakukan di beberapa Universitas di Indonesia seperti di Fakultas kedokteran Universitas Muhamadiyah Palembang dari hasil penelitian yang dilakukan oleh Legiran, Aziz, \& Bellinawati (2015), menunjukkan bahwa $50,8 \%$ mahasiswa mengalami stres dalam menumpuh studinya, mahasiswa kedokteran Universitas Riau juga mengalami stres dengan tingkat stres mencapai 57,23\% (Wahyudi, Bebasari, \& Nazriati 2015), Fakultas Kedokteran Universitas Lampung ditemukan prevalensi stres adalah 71\%, 23,6\% diantaranya adalah wanita dan $76,4 \%$ diantaranya adalah pria (Augesti, 2015). Penelitian sejenis juga telah dilakukan di Fakultas Kedokteran Universitas Andalas dimana tingkat stres terkait akademik, masuk dalam kategori stres berat yaitu mencapai 51,6\% (Rahmayani, Liza, \& Syah 2019). Sehingga dapat disimpulkan bahwa masih banyak mahasiswa kedokteran yang mengalami stres akademik dalam menempuh pendidikannya, selain itu stres juga dapat menjadi suatu ancaman yang dapat menyebabkan gangguan kejiwaan minor sampai pada tindakan bunuh diri.

Di Fakultas Kedokteran Universitas Halu Oleo sendiri, terdapat mahasiswa yang mengaku mengalami stres karena tuntutan akademik yang harus mereka penuhi, sehingga studi awal dilakukan dengan memberikan angket kepada 40 mahasiswa kedokteran Universitas Halu Oleo, hasilnya menunjukkan bahwa 38 mahasiswa mengaku pernah mengalami stres dalam menempuh studinya, dan 2 mahasiswa lainnya mengaku belum pernah mengalaminya, dari 38 mahasiswa yang mengaku mengalami stres, 29 mahasiswa diantaranya mengaku bahwa penyebab stres yang mereka alami disebabkan oleh beban belajar yang banyak, selain itu 26 mahasiswa juga mengaku bahwa ketakutan akan drop out dan tekanan akan keuangan merupakan bagian dari penyebab stres yang mereka alami selama menempuh studinya di Fakultas Kedokteran.

Hasil penyebaran angket juga menunjukkan bahwa stres yang mereka alami cukup menganggu aktivitas mereka sehari-hari, jika dilihat dari efek stres terhadap perilaku mereka, 28 mahasiswa mengaku sulit untuk beristirahat ataupun rileks, dan tidak jarang mahasiswa yang mengalami stres mengaku mengalami sakit kepala, kesulitan berkonsentrasi ataupun mengasingkan diri dari orang-orang disekitarnya, dan hal ini tentu saja akan mempengaruhi prestasi akademik yang mereka telah tentukan.

Wawancara juga dilakukan kepada ketua Program Studi (Kaprodi) Kedokteran Universitas Halu Oleo, dari wawancara tersebut didapatkan bahwa tidak jarang dari mahasiswa kedokteran memilih untuk pindah jurusan daripada bertahan dengan beban akademik yang mereka alami, selain itu beberapa mahasiswa juga memilih untuk pindah jurusan karena Indeks prestasi komulatif (IPK) yang menjadi standar evaluasi tiap tahun di Fakultas Kedokteran tidak terpenuhi. Hasil wawancara tersebut mengambarkan bahwa beberapa mahasiswa kedokteran tidak mampu untuk memenuhi tuntutan akademiknya, ketidakmampuan ini akan melahirkan perasaan tertekan yang pada akhirnya akan menimbulkan stres akademik (Kadapatti \& Vijayalaxmi, 2012).

Stres akademik yang mereka alami tentu saja berbeda-beda, ada mahasiswa yang mengalami stres akademik berat, dan ada juga yang mahasiswa mengalami stres akademik yang ringan, perbedaan ini dapat dipengaruhi oleh beberapa faktor diantaranya self-esteem (Nikitha, Jose, \& Valsara, 2014), kecerdasan emosional (Kauts, 2016), dan juga regulasi emosi (Wang \& Saudino, 2011). Namun dalam penelitian ini akan berfokus pada regulasi emosi yang dialami mahasiswa karena dalam regulasi emosi menjelaskan bahwa individu dapat mengurangi, meningkatkan 
ataupun mempertahankan emosi, tergantung pada tujuan dari individu itu sendiri (Gross \& Thompson, 2007), yang artinya mahasiswa dapat menyesuaikan emosi yang muncul akibat stres akademik yang mereka dialami dan dapat menyalurkannya ataupun mempertahankannya sesuai dengan keadaan yang tepat untuk mencapai suatu tujuan yang ingin dicapai, seperti mengurangi emosi negatif contohnya kemarahan, kesedihan, dan kecemasan (Gross, Richards, \& John, 2006), ataupun meningkatkan emosi positif seperti cinta, minat, dan kegembiraan (Quoidbach, Berry, Hansenne, \& Mikolajczak, 2010).

Gambaran mengenai regulasi emosi pada mahasiswa Fakultas Kedokteran Universitas Halu Oleo dapat dilihat dari respon mereka ketika menghadapai stres akademik. Dari pembagian angket kepada 40 mahasiswa ditemukan bahwa 10 mahasiswa mengaku bahwa ketika mereka mengalami stres akademik, mereka lebih memilih untuk menyendiri dibandingkan bercerita dengan orang lain, 20 mahasiswa lainnya juga mengaku akan merusak barang disekitarnya untuk membuat diri mereka merasa lebih baik, dan 28 mahasiswa lebih memilih untuk melakukan hal positif seperti refreshing dan juga menjalankan hobi mereka masing-masing. Mahasiswa yang mengaku mengalami stres akademik juga merasa lebih mudah marah dan merasakan kesedihan ataupun kemurungan selama mereka mengalami stres akademik tersebut.

Berdasarkan data di atas peneliti mengidentifikasi bahwa regulasi emosi yang dimiliki setiap mahasiswa kedokteran berbeda-beda, ada mahasiswa yang memiliki regulasi emosi yang baik dan ada juga mahasiswa yang memiliki regulasi emosi yang buruk. Perbedaan akan regulasi emosi ini mungkin saja akan mempengaruhi tingkat stres akademik yang dialami oleh mahasiswa.

Melihat dari data-data di atas, peneliti tertarik untuk melakukan penelitian yang berjudul hubungan antara regulasi emosi dengan stres akademik pada mahasiswa Fakultas Kedokteran Universitas Halu Oleo, apakah regulasi emosi yang baik yang dimiliki mahasiswa akan menghasilkan stres akademik yang rendah atau sebaliknya.

\section{Metode Penelitian}

Penelitian ini merupakan penelitian kuantitatif dengan menggunakan desain penelitian korelasional. Populasi dalam penelitian ini ialah mahasiswa di Fakultas Kedokteran Universitas Halu Oleo dengan total populasi sebanyak 373 mahasiswa yang terdiri dari angkatan 2015-2016. Teknik pengambilan sampel menggunakan Stratified Random Sampling, sehingga ditemukan total sampel sebanyak 79 mahasiswa. Metode pengumpulan data menggunakan Difficulties in Emotional Regulation Scale (DERS) oleh Gratz dan Roemer (2004), yang dimodifikasi oleh peneliti dan juga Student Academic Stres Scale (SASS) yang dimodifikasi oleh Wulandari (2018).

Data penelitian dianalisis dengan menggunakan teknik analisis data deskriptif dan juga teknik analisis data inferensial. Pada teknik analisis data inferensial peneliti menggunakan teknik analisis data korelasi Product Moment Pearson untuk menguji hipotesis dalam penelitian.

\section{Hasil Penelitian dan Pembahasan Hasil Penelitian \\ Analisis Deskriptif}

Hasil analisis deskriptif ditemukan kategorisasi stres akademik dan juga regulasi emosi pada mahasiswa. Subjek peneltian dikategorikan menjadi 5 kategori yakni sangat rendah, rendah, sedang, tinggi, dan sangat tinggi. Adapun hasilnya sebagai berikut : 
Tabel 1. Kategori Stres Akademik

\begin{tabular}{cccc}
\hline Skor & $n$ & $\%$ & Kategori \\
\hline $\mathrm{X}<88,856$ & 6 & $7 \%$ & Sangat Rendah \\
\hline $88,856<\mathrm{X}<121,298$ & 15 & $19 \%$ & Rendah \\
\hline $121,298<\mathrm{X}<153,740$ & 35 & $44 \%$ & Sedang \\
\hline $153,740<\mathrm{X}<186,182$ & 16 & $22 \%$ & Tinggi \\
\hline $186,182<\mathrm{X}$ & 7 & $8 \%$ & Sangat Tinggi \\
\hline
\end{tabular}

Berdasarkan hasil analisis di atas ditemukan bahwa stres akademik pada mahasiswa paling banyak ditemukan pada tingkatan stres akademik sedang dengan jumlah 35 orang mahasiswa, kemudian diikuti dengan tingkat stres akademik tinggi yakni sebanyak 16 orang dan yang paling sedikit ialah pada kategori rendah sebanyak 6 orang.

Tabel 2. Kategori Regulasi Emosi

\begin{tabular}{cccc}
\hline Skor & $n$ & $\%$ & Kategori \\
\hline $\mathrm{X}<68,034$ & 5 & $6 \%$ & Sangat Rendah \\
\hline $68,034<\mathrm{X}<85,045$ & 24 & $30 \%$ & Rendah \\
\hline $85,045<\mathrm{X}<101,372$ & 22 & $28 \%$ & Sedang \\
\hline $101,372<\mathrm{X}<118,041$ & 25 & $32 \%$ & Tinggi \\
\hline $118,041<\mathrm{X}$ & 3 & $4 \%$ & Sangat Tinggi \\
\hline
\end{tabular}

Kategorisasi pada variabel regulasi emosi pada mahasiswa paling dominan ditemukan pada kategori tinggi yang dialami oleh 25 mahasiswa, kemudian pada kategori rendah sebanyak 24 orang dan yang paling sedikit berada pada kategori sangat tinggi yakni 3 orang mahasiswa.

Tabel 3. Hubungan antara stres akademik dengan regulasi emosi berdasarkan kategorisasi

\begin{tabular}{ccccccc}
\hline \multirow{2}{*}{$\begin{array}{c}\text { Stres } \\
\text { Akademik }\end{array}$} & \multicolumn{7}{c}{ Regulasi Emosi } & Total \\
\cline { 2 - 6 } & $S R$ & $R$ & $S$ & $T$ & $S T$ & \\
\hline SR & - & - & - & 4 & 2 & 6 \\
\hline $\mathrm{R}$ & - & - & 5 & 10 & - & 15 \\
\hline $\mathrm{S}$ & 1 & 10 & 13 & 10 & 1 & 35 \\
\hline $\mathrm{T}$ & 1 & 10 & 4 & 1 & - & 16 \\
\hline $\mathrm{ST}$ & 3 & 4 & - & - & - & 7 \\
\hline Total & 5 & 24 & 22 & 25 & 3 & 79 \\
\hline Keterangan: & $\begin{array}{l}\text { SR (Sangat Rendah), R (Rendah), } \\
\text { (Tinggi) dan ST (Sangat Tinggi). }\end{array}$
\end{tabular}

Hasil uji silang untuk melihat hubungan antara stres akademik dengan regulasi emosi berdasarkan kategorisasi ditemukan bahwa mahasiswa memiliki stres akademik yang sedang dengan tingkat regulasi emosi yang sedang pula berjumlah 13 orang mahasiswa. Kemudian ditemukan hubungan positif yang tidak sesuai dengan hipotesis yang telah ditetapkan yakni hipotesis negatif pada 1 orang mahasiswa, dimana stres akademik yang dialaminya yakni masuk pada kategori tinggi dan regulasi emosi yang dialaminya juga masuk pada kategori yang tinggi pula.

\section{Analsisis Inferensial Uji Normalitas}

Hasil uji normalitas menjelaskan bahwa kedua data variabel penelitian terdistribusi normal, dimana variabel Stres akademik memiliki nilai $\rho=0,848$ ( $\rho>$ $0,05)$ dan variabel regulasi emosi memiliki $\rho=0,679(\rho>0,05)$. Adapun

\section{Tabel 4 Uji Normalitas}

\begin{tabular}{rll}
\hline Variabel & \multicolumn{1}{c}{ Signifikansi } & Keterangan \\
\hline Stres Akademik & 0,848 & Normal \\
\hline Regulasi Emosi & 0,679 & Normal \\
\hline
\end{tabular}

\section{Uji Linearitas}

Hasil Uji Linearitas ditemukan bahwa hubungan antara variabel stres akademik dan regulasi emosi memiliki hubungan linear, karena $\rho=0,000(\rho<$ $0,05)$.

Tabel 5 Uji Linearitas

\begin{tabular}{clcc}
\hline & & $F$ & Sig \\
\hline Stres Akademik & Linearity & 105,5 & 0,000 \\
X & Deviation & 63 & 0,126 \\
Regulasi Emosi & From & 1,462 & \\
& Linearity & & \\
\hline
\end{tabular}

\section{Uji Hipotesis}

Tabel 6. Uji Hipotesis

\begin{tabular}{llll}
\hline & & \multicolumn{1}{c}{$\begin{array}{c}\text { Stres } \\
\text { Akademik }\end{array}$} & $\begin{array}{c}\text { Regulasi } \\
\text { Emosi }\end{array}$ \\
\hline \multirow{3}{*}{$\begin{array}{l}\text { Stres } \\
\text { Akademik }\end{array}$} & $\begin{array}{l}\text { Pearson } \\
\text { Correlation }\end{array}$ & 1 & $-0,723^{* *}$ \\
\cline { 2 - 4 } & Sig. (2-tailed) & 79 & 0,000 \\
\cline { 2 - 4 } Regulasi & Pearson & $-0,723^{* *}$ & 1 \\
\hline Emosi & Correlation & 0,000 & \\
\cline { 2 - 4 } & Sig. (2-tailed) & 0 & 79 \\
\hline
\end{tabular}


Berdasarkan hasil uji hipotesis dengan teknik korelasi product moment diperoleh nilai signifikasi ( $\rho$ ) sebesar 0,000 , dimana nilai tersebut lebih kecil dari $0,05(\rho<0,05)$ yang artinya ada hubungan signifikan antara regulasi emosi dengan stres akademik. Nilai korelasi pearson menunjukkan angka -0,723, yang menunjukkan korelasi negatif yang kuat. Sehingga hasil penelitian ini menyatakan bahwa semakin tinggi regulasi pada mahasiswa maka semakin rendah stres akademik yang mereka alami dan begitupun sebaliknya.

\section{Pembahasan}

Hasil penelitian menunjukkan bahwa terdapat hubungan negatif signifikan antara kedua variabel tersebut. Korelasi negatif ini menunjukkan bahwa semakin tinggi stres akademik maka semakin rendah regulasi emosi yang dialami, begitupun sebaliknya semakin tinggi regulasi emosi semakin rendah stres akademik yang dialami.

Hasil penelitian ini relevan dengan penelitian sebelumnya, seperti penelitian yang dilakukan oleh Anwar (2018), yang berjudul hubungan antara regulasi emosi dengan stres akademik pada mahasiswa baru hasilnya menunjukkan bahwa, ada hubungan negatif signifikan antara regulasi emosi dan stres akademik. Lebih lanjut Evans dan Kim (2013), juga menyatakan bahwa regulasi emosi yang efektif dalam diri individu dapat melindungi efek negatif yang ditimbulkan oleh stres, dan begitupun sebaliknya stres juga dapat mempengaruhi jenis dan fleksibilitas strategi regulasi emosi yang digunakan. Gross, Richard, dan Jhon (2006), juga menyatakan bahwa regulasi emosi dapat menurunkan emosi negatif seperti kemarahan, kesedihan maupun kecemasan. Emosi negatif tersebut merupakan bagian dari gejala stres yang ditimbulkan akibat beban akademik yang harus mereka penuhi (Barseli \& Ifdil, 2017), artinya regulasi emosi dapat menekan stres dengan cara menurunkan emosi negatif yang muncul dalam diri individu. Hal serupa juga dikemukakan oleh Wang dan Saudino (2011), mereka menyatakan bahwa regulasi emosi yang baik dalam diri individu dapat menekan stres yang mereka alami. Secara fisiologis mereka juga menyatakan bahwa kerusakan pada korteks prefrontal dapat menyebabkan disregulasi emosi yang dapat menyebabkan kesulitan dalam pengaturan emosi yang disebabkan oleh stres.

Fakta maupun hasil riset yang menyatakan bahwa penurunan stres akibat dari regulasi emosi memperkuat hasil penelitian yang ditemukan, bahwa semakin tinggi regulasi emosi maka semakin rendah stres akademik yang dialami oleh mahasiswa begitupun sebaliknya, rendahnya kemampuan individu dalam regulasi emosi dapat membuat mahasiswa berada pada stres yang tinggi. Namun dalam analisis untuk melihat hubungan stres akademik dengan regulasi emosi berdasarkan kategorisasi, peneliti menemukan perbedaan pada 1 orang responden, hasil yang ditemukan ialah ada hubungan searah antara variabel regulasi emosi dengan stres akademik dan hal ini tentu berlawanan dengan uraian hipotesis di atas. Berdasarkan tinjauan literatur peneliti menemukan bahwa banyak variabel-variabel maupun faktor lain yang memiliki hubungan dengan stres akademik seperti kecerdasan emosional (Kauts, 2016) maupun self-esteem (Nikitha, Jose, \& Moodi, 2013) yang ada dalam diri individu, sehingga perbedaan stres akademik terhadap regulasi emosi yang berbeda ini bisa saja dipengaruhi oleh variabel lain selain dari regulasi emosi sehingga hubungan searah ditemukan pada 1 responden.

Analisis deskriptif dalam penelitian ini menunjukkan kategorisasi stres akademik dari stres akademik yang sangat ringan sampai pada stres akademik yang sangat berat, dimana hasilnya menunjukkan bahwa sebanyak 6 mahasiswa termasuk dalam kategorisasi stres yang sangat ringan, kemudian sebanyak 15 mahasiswa berada pada 
kategori stres yang ringan, 35 mahasiswa teridentifikasi mengalami stres pada kategori sedang, selanjutnya pada tingkat stres berat juga dialami oleh 16 mahasiswa dan tingkatan kategori terakhir yakni stres sangat berat dialami oleh 7 mahasiswa.

Hasil data di atas menjelaskan bahwa stres akademik pada mahasiswa kedokteran paling banyak dialami pada kategori sedang yakni sebanyak 35 orang. Stres akademik pada mahasiswa berbedabeda, perbedaan ini dapat disebabkan oleh faktor eksternal seperti pelajaran yang padat dan juga tekanan dari lingkungan untuk berprestasi (Barseli \& Ifdil, 2017). Pelajaran yang lebih padat dan juga tekanan dari lingkungan untuk berprestasi merupakan tuntutan akademik yang harus mereka penuhi, dan apabila tuntutan yang mereka alami melebihi sumber daya adaptif yang ada dalam diri mereka, maka stres akademik akan dialami oleh mahasiswa (Wilks, 2008). Sumber daya adaptif inilah yang menjadi pusat mengapa stres akademik pada mahasiswa berbedabeda, padahal tuntutan akademik yang mereka hadapi itu sama. Gross dan Thompson (2007), mejelaskan bahwa regulasi emosi dapat mengurangi, meningkatkan atau mempertahankan emosi tergantung pada tujuan individu, hal ini secara langsung menegaskan bahwa regulasi emosi merupakan suatu kemampuan adaptif yang ada dalam diri individu untuk menyesuaikan diri dengan keadaan akibat dari stres akademik yang dialami.

Selain analisis data deskriptif pada variabel stres akademik, peneliti juga mendeskripsikan tingkatan regulasi emosi pada subjek penelitian, hasilnya menunjukkan bahwa sebanyak 5 mahasiswa berada pada regulasi emosi yang sangat rendah, kemudian 24 mahasiswa berada pada kategori yang rendah, dan 22 mahasiswa berada pada tingkatan regulasi emosi yang sedang, sedangkan 25 mahasiswa lainnya berada pada kategori yang tinggi dan 3 mahasiswa berada pada kategori yang sangat tinggi.
Data di atas menjelaskan bahwa kategorisasi regulasi emosi pada mahasiswa kedokteran paling banyak dialami pada kategori yang tinggi yakni sebanyak 25 mahasiswa. Semakin tinggi kategorisasi regulasi emosi yang didapatkan maka semakin baik regulasi emosi yang dialami, begitupun sebaliknya semakin rendah tingkat regulasi emosi maka semakin buruk kemampuan regulasi emosi seseorang. Mahasiswa dengan regulasi emosi yang baik memiliki kesadaran diri emosional, mampu mengelola emosi, dapat memanfaatkan emosi secara produktif, memiliki empati dan juga dapat membina hubungan dengan baik (Goleman, 2016). dan hal tersebut dapat mempengaruhi stres akademik yang dialami oleh mahasiswa.

Uraian di atas menjelaskan bahwa regulasi emosi pada mahasiswa berbedabeda, banyak faktor yang mempengaruhinya, beberapa diantaranya ialah pola asuh, dan juga kepribadian (Anggreiny, 2014). Cara orang tua dalam mendidik anak akan membentuk kemampuan anak dalam meregulasi emosinya, tergantung dari jenis pola asuh yang diterapkan oleh orang tuanya, selain itu faktor kepribadian juga mempengaruhi kemampuan regulasi emosi pada mahasiswa, mahasiswa dengan kepribadian neuroticism dengan ciri-ciri sensitif, suka gelisah, dan sering merasa cemas akan menunjukkan regulasi emosi yang rendah, dan tentu akan berbeda dengan individu dengan tipe kepribadian yang sebaliknya

\section{Keterbatasan Penelitian}

1. Ada beberapa variabel yang memiliki hubungan dengan dengan stres akademik selain regulasi emosi, yang tidak dapat dikontrol oleh peneliti.

2. Peneliti tidak mengkategorisasi karakteristik mahasiswa berdasarkan jenis kelamin, sehingga dalam penelitian tidak mengambarkan perbedaan stres akademik antara lakilaki dan perempuan pada mahasiswa kedokteran. 


\section{Kesimpulan dan Saran Kesimpulan}

Berdasarkan hasil penelitian maka dapat disimpulkan bahwa ada hubungan signifikan antara regulasi emosi dengan stres akademik pada mahasiswa kedokteran Universitas Halu Oleo, lebih lanjut peneliti menemukan hubungan negatif antara regulasi emosi dengan stres akademik, sehingga dapat diartikan bahwa semakin tinggi stres akademik maka semakin rendah regulasi emosi yang dialami oleh mahasiswa.

Analisis deskriptif juga menjelaskan bahwa stres akademik pada mahasiswa kedokteran paling banyak dialami pada kategori yang sedang yakni sebanyak 35 orang dan pada regulasi emosi paling banyak dialami pada kategori yang tinggi yakni sebanyak 25 orang.

\section{Saran}

\section{Bagi Subjek Penelitian.}

Stres akademik yang dialami oleh mahasiswa tidak dapat dihilangkan maka harus dapat dihadapi, oleh sebab itu diharapkan kepada mahasiswa untuk meningkatkan kemampuan adaptif yang ada dalam dirinya, artinya mahasiswa diharapkan dapat menyesuaikan diri dengan keadaan akibat dari stres akademik yang mereka alami. Dalam hal ini peneliti menyarankan untuk meningkatkan kemampuan dalam meregulasi emosi karena regulasi emosi dapat menurunkan emosi negatif yang disebabkan oleh stres akademik sehingga paparan stres yang dialami dapat diminimalisir. Peningkatan tersebut dapat dilakukan dengan melihat strategi regulasi emosi seperti, memodifikasi keadaan, mengarahkan perhatian dalam hal ini mengalihkan perhatian dari situasi yang tidak menyenangkan, melakukan perubahan kognitif dengan tujuan untuk menambah atau mengurangi emosi positif maupun negatif, dan juga melakukan perubahan respon seperti melakukan olahraga maupun relaksasi untuk mengurangi respon emosi negatif.

\section{Bagi Peneliti Selanjutnya.}

1. Melakukan penelitian lebih lanjut dengan menambahkan faktor-faktor lain misalnya korelasi antara regulasi emosi dengan stres akademik pada mahasiswa kedokteran yang mengikuti ekstrakurikuler ataupun lainnya.

2. Peneliti juga menyarankan untuk menambahkan variabel penelitian lain seperti self esteem, kecerdasan emosional ataupun variabel penelitian lainnya untuk melihat sumbangsi efektif antar variabel.

3. Dalam proses pengambilan data awal, peneliti menyarankan untuk melakukan observasi ataupun wawancara mendalam untuk mendapatkan gambaran rinci bagi mahasiswa yang mengalami stres akademik maupun regulasi emosi dalam diri mereka.

4. Mengkategorikan tingkatan kedua variabel berdasarkan jenis kelamin.

\section{Daftar Pusataka}

Alsulami, S., Omar, Z. A., Binnwejim, M. S., Alhamdan, F., Aldrees, A., Albawardi, A., Alsohim, M., \& Alhabeeb, M. (2018). Perception of academic stres among health science preparatory program students in two saudi universities. Advances in Medical Education and Practice. 9. 159-164. doi: 10.2147/AMEP.S143151

Anggreiny, N. (2014). Rational emotive behaviour therapy (REBT) untuk meningkatkan regulasi emosi pada remaja korban kekerasan seksual. (Thesis). Universitas Sumatra Utara, Medan, Indonesia.

Anwar, K. (2018). Hubungan antara regulasi emosi dengan stres akademik pada mahasiswa baru. (Skripsi). Universitas Islam Negeri Sunan Kalijaga Yogyakarta, Yogyakarta, Indonesia. 
Augesti, G. (2015). Perbedaan tingkat stres antara mahasiswa tingkat awal dan tingkat akhir fakultas kedokteran universitas lampung. (Skripsi). Universitas Lampung, Bandar Lampung, Indonesia.

Barseli, M., \& Ifdil, I. (2017). Konsep stres akademik siswa. Jurnal Konseling dan Pendidikan, 5(3), 143-148. doi: 10.29210/119800

Evans, G. W., \& Kim, P. (2013). Childhood poverty, chronic stress, self-regulation, and coping. Child Development Perspectives, 7(1), 43-48.

Geng, R \& Midford, R. (2015). Investigating first year education students' stress level. Australian Journal of Teacher Education. 40(6), 1-12. doi : 10.14221/ajte.2015v40n6.1

Goleman, D. (2016). Emotional intelligence. Mengapa ei lebih penting dari pada IQ. Translated: T. Hermaya. Jakarta: PT. Gramedia Pustaka Utama.

Gratz, K. L., \& Roemer, L. (2004). Multidimensional assessment of emotion regulation and dysregulation: development, factor structure, and initial validation of the difficulties in emotion regulation scale. Journal of Psychopathology and Behavioral Assessment. 26(1), 4154. doi: 10.1023/B:JOBA.0000007455.08 539.94

Gross, J.J., \& Thompson, R.A. (2007). Emotion regulation conceptual. Handbook of Emotion Regulation, Edited by James J. Gross. New York: Guilfors Publication.

Gross, J. J., Richards, J. M., \& John, O. P. (2006). Emotion regulation in everyday life. Washington, DC: American Psychological Association.

Hartaji, D. A. (2012). Motivasi berprestasi pada mahasiswa yang berkuliah dengan jurusan pilihan orang tua. (Skripsi). Fakultas Psikologi Universitas Gunadarma.

Jafri, S. A. M., Zaidi, E., Aamir, I. S., Aziz, H. W., Din, I. U., \& Shah, M. A. H. (2017). Stres level comparison of medical and nonmedical students: a cross sectional study done at various professional colleges in karachi, pakistan. Acta Psychopathologica, 3(2), 1-6. doi: 10.4172/2469-6676.100080

Kadapatti, M., \& Vijayalaxmi, A. H. M. (2012). Stressors of academic stress-A study on Pre-University Student. Indian Journal of Scientific Research,3(1), 171-175.

Kauts, D.S. (2016). Emotional intelligence and academic stress among college Students. Journal of Education and Applied Social Sciences. 7(3), 149-157.

Legiran, Azis, M. Z., \& Bellinawati, N. (2015). Faktor risiko stres dan perbedaannya pada mahasiswa berbagai angkatan di fakultas kedokteran universitas muhammadiyah palembang. Jurnal Kedokteran Dan Kesehatan, 2(2), 197-202.

Nikitha, S., Jose, T .T., \& Valsaraj, B. P. (2014). A correlational study on academic stress and self esteem among higher secondary students in selected schools of udupi district. Nitte University Journal of Health Science, 4(1), 106-108.

Olape, O. R., Lasiele, A. Y, Chiaka, A. E., \& Abidoye, T. K. (2017). Stress level and academic performance 
of university students in kwara state, nigeria. Makerere Journal of Higher Education. 9(1), 103112. doi : 10.4314/majohe.v9i1.9

Quoidbach, J., Berry, E. V., Hansenne, M., \& Mikolajczak, M. (2010). Positive emotion regulation and well-being: Comparing the impact of eight savoring and dampening strategies. Personality and Individual Differences, 49, 368373.

doi:10.1016/j.paid.2010.03.048

Rahmayani, R. D., Liza, R. G., \& Syah, N. A. (2019). Gambaran tingkat stres berdasarkan stresor pada mahasiswa kedokteran tahun pertama program studi profesi dokter fakultas kedokteran universitas andalas angkatan 2017. Jurnal Kesehatan Andalas, 8(1). 103-111. doi: 10.25077/jka.v8.i1.p103111.2019

Wahyudi, R., Bebasari, E., \& Nazriati, E. (2015). Gambaran tingkat stres pada mahasiswa fakultas kedokteran universitas riau tahun pertama. JIK, 9(2), 107-113. doi: 10.26891/jik.v9i2.2015.107-113

Wang, M \& Saudino, K. J. (2011). Emotion regulation and stress. Journal of Adult Development. 18(2), 95-103. doi :10.1007/s10804-010-9114-7

Wilks, S. E. (2008). Resilience amid academic stress: the moderating impact of social support among social work students. Advances in Social Work. 9(2),106-125. doi: $10.18060 / 51$

Wulandari, D. (2018). Hubungan antara regulasi diri dalam belajar dan stres akademik pada mahasiswa kedokteran. (Skripsi). Universitas
Islam Indonesia, Yogyakarta, Indonesia

York, Y. T., Gibson, C., \& Rankin, S. (2015). Defining and measuring academic success. Practical Assessment, Research \& Evaluation, 20(5), 1-20.

Yusoff, M. S. B., Fuad, A., Rahim, A., Baba, A. A., Ismail, S. B., Pa, M. N. M., \& Esa, A. R., (2013). Prevalence and associated factors of stress, anxiety and depression among prospective medical students. Asian Journal of Psychiatry. 6(2), 128-133. doi: 10.1016/j.ajp.2012.09.012 